\title{
Research on MOOCs: Trends and Methodologies
}

InMaCulada Maiz Olazabalaga

Carlos Castaño Garrido

URTZA GARAY RUIZ

University of the Basque Country

Received: 7 October 2015 / Accepted: 30 November 2016

ISSN: $1697-7467$

\begin{abstract}
The MOOC phenomenon has generated huge interest in the field of education from the outset, giving rise to a significant number of research studies. In this paper we will take a look at previous research into MOOCs and we believe the relevant research trends from the education perspective will focus on new developments in hybrid MOOCs, both in their technological and pedagogical aspects, and in placing students' learning and academic results at the forefront of research. The use of more sophisticated research designs is also recommended, paying greater attention to causal factors that promote student learning.

Keywords: Instructional innovation, learning process, educational research, educational technology
\end{abstract}

\section{Investigación en MOOC: tendencias y metodologías}

RESUMEN: El interés despertado por el fenómeno MOOC en la educación ha generado casi desde sus comienzos un buen número de estudios de investigación. En este trabajo, repasamos la investigación precedente en MOOC y consideramos que las tendencias de investigación relevantes desde la educación se centrarán en los nuevos desarrollos de MOOC híbridos, tanto en sus aspectos tecnológicos como pedagógicos, y en situar el aprendizaje y el resultado académico de los estudiantes como punto central de la investigación. Se recomienda igualmente la utilización de diseños de investigación más sofisticados que presenten atención a factores causales que promuevan el aprendizaje de los estudiantes.

Palabras clave: Innovación educativa, proceso de aprendizaje, investigación educativa, tecnología educativa

\section{INTRODUCTION}

Since they were created in 2008, MOOCs (Massive Open Online Courses) have been receiving a lot of attention in scientific literature, representing a new way of approaching training that is attracting millions of students all over the world, and which is changing the way traditional, brick-and-mortar universities perceive online education. This has occurred to such an extent that Brooks (2012) referred to them as the tsunami on campus, as the phenomenon that, in one stroke, would change university forever (García Aretio, 2015).

This interest in MOOCs shown by the academic community has resulted in the body of research that has gradually been constructed around MOOC projects since 2008. Contributions from authors such as Liyanagunawardena, Adams \& Williams (2013); Castaño (2013); 
Kennedy (2014); Jordan (2014) Gasevic, Kovanovic, Joksimovic \& Siemens (2014), Yousef, Chatti, Schroeder, Wosnitza \& Jakobs (2014); Chiappe-Laverde, Hine \& Martínez-Silva (2015); Sangrá, González- Sanmamed \& Anderson (2015) and Meyer (2015) are testimony to this.

This body of research is recent, and shows that high impact scientific output is still in its infant stages and is yet to be properly developed, paying greater attention to a theoretical approach than to empirical postulates López-Meneses, Vázquez-Cano \& Román (2015).

In this paper we will briefly analyse previous research into MOOCs (highly fragmented) and then, in the following section, we will single out the two more promising research trends in the near future: the interest in hybrid MOOCs and in the students' learning results. The most promising research studies currently in progress will be based on these two trends and organised around pedagogical, technological and strategic aspects.

We will also look into the research methodologies employed to date and will recommend researching the actual educational potential of MOOCs and carrying out more methodologically sophisticated studies.

\section{Current state of affairs}

The research community has been particularly active on this topic, which explains why we find, almost from the beginning of MOOCs, different studies based on their results. Two stages can be distinguished: studies based on reviewing works published until 2012 (a period when references were relatively few) and studies based on reviewing works published in 2013 and 2014 (by which time references had become much more numerous).

In the first period, Liyanagunawardena, Adams \& Williams (2013) reviewed the research studies referring to MOOCs between 2008 and 2012 and pointed out four particularly relevant research topics: (1) the need to explore different perspectives as regards all the parties involved in MOOCs (students, creators, teachers, institutions, etc.), bearing in mind the advantages and disadvantages of each point of view; (2) the cultural tensions within the MOOC pedagogies, resources and learning environments; (3) the ethical aspects in the use of data generated as part of the MOOC; and (4) an analysis of the students' efficient strategies to deal with the overload of information and self-regulated learning.

A more synthetic review was carried out by Castaño (2013), who suggests grouping previous studies together in three main lines of research: pedagogical design, network effect (analysis of the students' interactions in a MOOC project) and academic performance and associated variables: motivation, attitudes and perspectives.

Lastly, Kennedy (2014) carried out a review of existing literature from 2009 to 2012, focused solely on scholarly research in the hope of improving understanding and communication about the characteristics associated with MOOCs, in which she recommends focusing future research into MOOCs on three main areas: 1) improving student understanding, their types of behaviour and the social nature of learning; 2) the vast differences in pedagogical approach between the two classical MOOC models; 3) the implications of MOOCs' incorporation into formal education institutions.

Jordan (2014), rather than offering a systematic review of MOOC research, presents an online draft of the research literature on MOOCs that includes over 250 references, to which 
she associates keywords and tags. The participation of students in a MOOC stands out from the tag cloud, followed by measurement and assessment (advances in automatic assessment, peer assessment, etc.), dropout rates and the students' demographic characteristics.

In these initial works we observe how the authors recommend that research be focused not on the technological aspects of the MOOCs, but rather on the genuinely pedagogical aspects, such as differences in how MOOCs are designed, self-regulated learning, students' perspectives or the integration of MOOCs in formal education.

From 2013 onwards, an increasing number of studies in scientific journals presented research results in connection with MOOCs and were subsequently reviewed. The review put together by Yousef et al. (2014) was a nexus between both periods. An analysis of the 84 studies we selected from the 2008-2013 period suggests an interest in the aforementioned research topics, but also in the technological aspects (automatic assessment, peer assessment, etc.) and for research methodology aspects.

Gasevic et al. (2014) have analysed the research proposals submitted to the MOOC Research Initiative (MRI), funded by the Gates Foundation (2013) and administered by Athabasca University. The results have revealed the main research topics that make up the framework of future MOOC research: 1) student participation and academic performance; 2) MOOC design and curriculum; 3) self-regulated learning and social learning; 4) social network analysis and online learning; and 5) motivation, attitude and academic success.

Chiappe-Laverde et al. (2015) use a different approach, based on good practices and on an analysis of the practical training experiences with MOOCs at university. These authors lament the failing interest in the pedagogical aspects of most of these training proposals (in favour of the platforms themselves) and they identify at the same time new relevant research topics: opening up education, the relationship between MOOCs and reusing content, connectivism and peer learning, among others.

Sangrá et al. (2015) have carried out a meta-analysis of the research into MOOCs that was developed over the 2013-14 period, focusing on publications that present MOOCrelated research results. The identified 228 research studies in the two-year period they analysed. Results have been organised according to categories related both to pedagogical aspects (role of social media in learning, pedagogical strategies, comparison between hybrid courses and traditional MOOCs) and to technological (modelling/machine learning, natural language processing, human-computer interaction) and methodological aspects (educational data mining, learning analytics).

Lastly, Castaño, Maiz \& Garay (2015a) believe that the pedagogical design of MOOCs, interaction between students and learning perspectives and their associated variables (motivation, attitudes) stand out as the most significant lines of research. Alongside this learning-based perspective, we also find matters related to cost, universal accessibility to higher education, the problem of student dropout rates, as well as the problem of their integration in formal university studies.

In the following section, we will summarise these different perspectives into two basic trends which will set the tone for future research by integrating the different pedagogical, technological and strategic aspects to be taken into account. 


\section{Research Trends in MOOCs}

The current state of affairs as regards research into MOOCs can be classified as fragmented, taking into account the different authors' varying epistemological and ontological conceptions as to what should actually be studied. One of the most relevant research issues continues to be the pedagogical design of MOOC proposals, as highlighted by Gasevic et al. (2014), and Castaño et al. (2015a), among others.

Nevertheless, it is important to bear in mind that the MOOC concept, despite being relatively new, is a polysemic concept in a constant state of transformation. So, in spite of the fact that MOOCs use a flexible type of teaching with little standardisation (Shirky, 2013), different authors suggest a distinction should be made between "connectivist" cMOOCs and more "traditional" xMOOCs (Siemens, 2012; Rodriguez, 2013). For this reason, early research studies (Rodríguez, 2012) dealt with the representative courses of Artificial Intelligence (AI) at Stanford (Udacity, Coursera) and cMOOC formats in detail. This initial classification proved to be too simplistic and has gradually gained in complexity (Conole, 2013) with proposals such as those put forward by Knox, Bayne, MacLeod, Ross \& Sinclair (2012), or Lane (2012), who have found certain difficulties in placing their proposals within the "Stanford model" versus "connectivist" MOOC dilemma.

From here on, new proposals have been put forward, such as cooperative MOOCs (Fidalgo, Sein-Echaluze \& García Peñalvo, 2013), who endeavour to respond to the heterogeneity of participants in a MOOC by using an x-type course but including some of the advantages of connectivist courses, or dual layer MOOCs (Siemens, 2014) that enable the students, throughout the course, to choose one or the other (xMOOC or cMOOC) as they wish. It must also be pointed out that, recently, new types of MOOCs have appeared. One such example are sMOOCs (small open online courses), some of them supported by European projects like ECO (Elearning, Communication and Open-Data, 2015: Massive, Mobile, Ubiquitous and Open Learning) and using learning analytics and web 2.0, among other aspects. Another example are blended MOOCs, a hybrid proposal that offers both online and classroom teaching.

However, hardly any studies have dealt with the influence of certain types of MOOC design on learning results Castaño et al. (2015a). So the references in constructivist courses (Kop, Fournier \& Mak, 2011; De Waard et al., 2011) focus more on how they transform conventional knowledge-generating structures than on a strict measurement of learning results. Furthermore, the sheer volume of data generated by research into traditional MOOCs tells us more about what the students are doing than what they are learning (Reich, 2015). Mixed proposals, which are where MOOCs are heading and which are also the first to be concerned with studying the students' performance, are interested in a search for proposals that facilitate the insertion of MOOCs in formal, regulated teaching, both at a university level (Delgado Kloos, Muñoz-Merino, Alario-Hoyos, Estevez Ayres \& Fernández Panadero, 2015) and at secondary education level (Israel, 2015).

Hybrid MOOCs will catch researchers' attention, as Hollands \& Tirthali (2014) already suggested when they pointed out the comparison between hybrid MOOCs and other traditional courses as one of the most advanced lines of research, and in which the institution managers interviewed in their study expressed an interest. The second main line that will lead research studies in the next stage will be an interest in students' learning (Reich, 2015). Below we have made a brief outline of the main pedagogical, technological and strategic aspects of these two premises. 


\subsection{Technological aspects}

MOOCs offer students collaborative spaces in which to interact and strengthen their work with the support of a wide range of tools, from traditional forums to the use of their own Web 2.0 social networks and Facebook groups. Hybrid, cooperative, adaptive and other such MOOCs boost the use of social networks, which generates at least two types of problem: 1) a huge amount of data and information that can not be studied in depth; and 2) difficulty to respond to a massive number of students. The use of new tools has become essential to be able to apply the learning analytics to measure, compile, analyse and present the students' data as well as that from their contexts, with the purpose of understanding and optimising learning and the environments in which it is produced (Ferguson, 2012).

Sangrá et al. (2015) already warned us of the rise in research focused on educational data mining and learning analytics, including work such as those on browsing strategies according to age and country of origin (Guo \& Reibnecke, 2014). New research projects that propose a technological framework in which to integrate xMOOC and cMOOC learning strategies, which have the capacity to adapt and manage the generated knowledge both in the formal and informal learning arena (Fidalgo, Sein-Echaluce \& García Peñalvo, 2015), show the direction in which these new studies are going.

From another perspective, other advances related to improvements in technological solutions such as modelling/machine learning, natural language processing, human-computer interaction, adapting machines in line with the student's progress (Vargas, 2014), or the development of new tools such as video annotations, which allow for greater multimedia interaction and collaboration between students (Monedero, Cebrián \& Desenne, 2015), are all opening new research prospects.

\subsection{Pedagogical aspects}

The studies carried out to date from a technological perspective have focused mainly on desk research (Reich, 2015), as we have seen in the evolution of MOOCs' pedagogical design. There are, however, also a significant number of experimental research studies dealing with the evaluation of pedagogical strategies and, in particular, with student motivation and engagement (Sangrá et al., 2015).

Motivation has already been identified by Milligan, Littlejohn \& Margaryan (2013) as a variable that contributes to increasing students' participation and success. Contributions in this area have come from several authors, including Cheng (2014), who deals with the emotional competence of students on a MOOC, Veletsianos (2013), on learning experiences with MOOCs, and Castaño, Maiz \& Garay (2015b) on students' learning perspectives. Other research examples include those by Anderson \& Ponti (2014) on instructional strategies, on co-creation of content and participatory pedagogy. Lastly, studies into students' engagement with the MOOC in question, types of student, participation and dropout rates are also often covered.

Nevertheless, advances in knowledge and awareness of MOOCs means that richer methodological designs will be needed, which will enable more attention to be paid to the causal factors that promote students' learning (Reich, 2015). Studies such as that presented by Guo, Kim \& Rubin (2014), analysing the characteristics that videos must have 
in order to be efficient in a MOOC, or those presented by Zhang, Gad \& Van Mieghem (2015) on the increase in students' performance through interaction on social networks and forums, all point in this direction. Likewise, the implications of MOOC for teaching, both online and in the new emerging digital training scenarios, will highlight the analysis of the roles and competences that students and teachers must acquire in order to be successful in these proposals.

The assessment of learning in MOOCs is the other important variable that we must take into account. Following on from the works of Sandeen (2013), a powerful field of research opened up, dealing with the different dimensions of learning as well as the variety of students and a range of assessment techniques: e-assessment, peer-assessment and selfassessment (Gallego, Gámiz \& Gutiérrez, 2015). Furthermore, the MOOCs' own quality assessment, which universities are undoubtedly interested in, opens new research prospects (Lowenthal \& Hodges, 2015).

\subsection{Strategic aspects}

The strategic aspects are related to academic institutions' interest in MOOCs as a contribution to meet the demands of formal education. To this effect, Yuan \& Powell (2013) point out that it might be a mistake to consider MOOCs as a new isolated development on which to make strategic decisions, given that they form part of a wider landscape of changes in higher education, underlining their potential to improve education and to promote innovation and new pedagogical practices. Furthermore, Hollands \& Tirthali (2014) believe that MOOCs must be understood in formal training environments as educational resources to supplement classroom teaching rather than as independent courses in their own right, and which should possibly be aimed at specific targets: university students with the chance to validate credits, professional development courses for teachers, or as a channel for corporate training. On the same line, Dillenbourg, Fox, Kirchner, Mitchell \& Wirsing (2014). identified the subject of integrating MOOCs in university education as the main challenge at this moment in time.

The search for new instructional formats with new digital training environments coming from MOOCs is already resulting in many research studies, and this looks to be on the rise. Whereas research initially focused on replacing classroom hours (as specified in the curriculum) with online classes by means of MOOCs (Vihavainen, Luukkainen \& Kurhila, 2013), the main current trend is to complement the curriculum in different ways with MOOCs.

Bruff, Fisher, McEwen \& Smith (2013), for example, invite their students from the campus to take part in a Coursera MOOC, but maintain classroom interaction. Fidalgo, Sein-Echaluce, Borrás \& García Peñalvo (2014) also incorporate the learning resources of a MOOC into a module. Firmin, Schiorring, Whitmer \& Willett (2014), however, use a MOOC created by themselves in collaboration with Udacity (but offered openly as reference material) to develop a flipped classroom methodology. These studies suggest that educational institutions are leaning towards hybrid and blended formulas as a method for using MOOCs in formal education contexts (Castaño et al., 2015b; Delgado Kloos et al., 2015; Israel, 2015). 


\section{RESEARCH MATURITY}

The existence of a high number of MOOC research reviews cannot hide the criticism that has come from many researchers who find that high impact scientific ouput is in its early stages and is still not properly developed, paying greater attention to a theoretical approach than to empirical postulates (López-Meneses, et al., 2015). This opinion is one that is shared by Cabero (2015), who believes in boosting research into the real educational possibilities offered by MOOCs beyond mere favourable or unfavourable opinions that are not based on evidence.

A number of factors may explain this limitation. On one hand, as we have seen, there is the complexity of the term itself, which is in constant transformation. This impetus explains how the theoretical approach to the MOOC phenomenon is still significant.

A second factor that has a bearing on the lack of research maturity is explained with the Gartner firm's annual Hype Cycle report regarding acceptance of any technology, and which indicates that there are different phases and moments specified as: technology trigger, peak of inflated expectations, trough of disillusionment, slope of enlightenment, and plateau of productivity. The evolution of MOOCs since the years 2012-2014 is shown in Figure 1 , in which we can see how we are progressively approaching the plateau of productivity, which will presumably lead to greater maturity of the technology itself.

Figure 1.: Gartner's Hype Cycle of emerging technologies and MOOC position. Adapted from Cabero (2015:53).

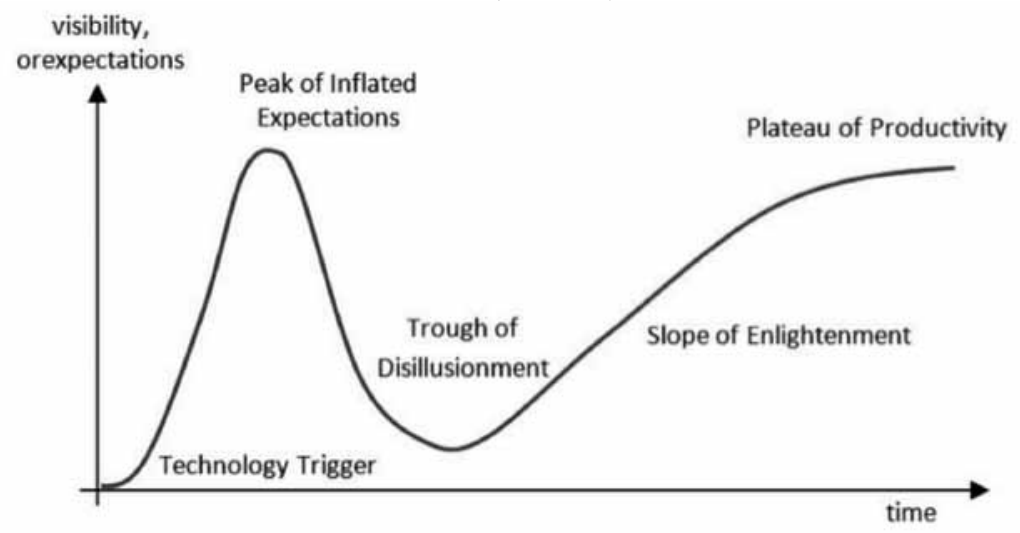

The epistemological maturing process also brings with it a degree of fragmentation in the methodologies used for the study. Raffaghelli, Cucchiara \& Persico (2015), in their review of the methodologies used in researching MOOCs, conclude that we are currently at the very early stages, dominated by desk research and descriptive studies (qualitative and quantitative). The use of empirical methodologies is generally limited to case studies. Furthermore, the experimental studies are usually small-scale, with frequencies based on a case study of a single MOOC. The studies in question are not very sophisticated and are 
more aimed at understanding the phenomenon and constructing hypotheses than at answering specific research questions.

These research methodologies are suitable for an initial or exploratory stage, coinciding with the initial phases of the "full cycle of educational research" (Gorard, 2004; Gorard \& Cook, 2007). Educational research in a given field is developed through a seven-phase development cycle, from recognition of the existence of a problem, to the development of studies aimed at proposing solutions, to analysing a specific impact or achieving technology transfer.

These studies confirm the fact that we are at the early stages of development as regards research into MOOCs, devoted to characterising the object of study, conceptualising the phenomena and identifying more clearly and systematically the main research problems (Raffaghelli et al., 2015). Reich (2015) summarises some of these research topics as follows: 1) from investigations of individual courses to comparisons across contexts; and 2) from a reliance on post hoc analyses to a greater use of multidisciplinary, experimental design.

\section{Discussion ANd CONClusions}

Although MOOCs, as a concept, may be seen as a relatively recent phenomenon, they have generated considerable interest in the research community. Their potential as an element to innovate or even revolutionise classical online education by generating new education models explains why so many researchers are interested in studying them. This interest is shared by the universities, as MOOCs can affect their pedagogical, organisational and business models. To this effect, the search for new pedagogical formats with new digital training environments coming from MOOCs is one of the emerging research topics.

Reviewing research studies on MOOCs has highlighted a number of significant weaknesses. First, the variety of MOOCs in existence. It is worth mentioning that the term MOOC can be used to refer to anything from the first, more connectivist cMOOCs to the now preeminent XMOOCs, as well as mixed models (such as blended MOOCs) which often seek to integrate different types of MOOCs in formal education environments. Another clearly highlighted aspect is the weakness of the research methods used, where desk research and case studies have been most prominent. Both factors largely explain the existence of such a fragmented research field.

Those initial weaknesses have gradually been overcome as research on MOOCs has reached a level of maturity. This maturity stage is also characterised by a shift in the researchers' interest towards research projects with greater scientific rigour and focusing more on what the student is really learning than what he or she is doing on a MOOC. Hybrid MOOCs are also identified as the most important trend in the development of educational models. It is also worth mentioning the increasing use of learning analytics and of tools that help visualise, manage and exploit data from the social dimension of learning (and informal learning).

The topics put forward in this paper may help to create an agenda of research methodologies and topics that will lead the MOOC phenomenon to a level of maturity, which will, in turn, enable it to offer more interesting contributions in the field of teaching and learning in massive open training contexts. 


\section{REFERENCES}

Andersen, R. and Ponti, M. (2014). "Participatory pedagogy in an open educational course: challenges and opportunities". Distance Education, 35, 2, 234-249, available from: http:// www.tandfonline.com/doi/abs/10.1080/01587919.2014.917703, accessed 9 September, 2015.

Brooks, D. W. (2012). "The campus tsunami”, in New York Times (4-5-2012), 3, A29.

Bruff, D.O., Fisher, D.H., McEwen, K.E. \& Smith, B.E. (2013). "Wrapping in a MOOC: student perceptions in blended learning". Journal of Online Learning and Teaching, 9, 2: 187-199, available from: http://jolt.merlot.org/vol9no2/bruff_0613.htm, accessed 8 September, 2015.

Cabero, J. (2015). "Educational visions of MOOC". RIED, 18, 2: 39-60, available from: http:// revistas.uned.es/index.php/ried/article/view/13718, accessed 9 September, 2015.

Castaño, C. (2013). "Tendencias en la investigación en MOOC. Primeros resultados". In IKASNABAR, 2013, VI Congreso Internacional de Educación Abierta y Tecnología, available from: http:// ikasnabar.com/papers/castano1/, accessed 15 July, 2015.

Castaño, C., Maiz, I. and Garay, U. (2015a). "Design, Motivation and Performance in a Cooperative MOOC Course". Comunicar. Revista Científica de Educación y Comunicación, 44: 19-26, available from: http://www.revistacomunicar.com/verpdf.php?numero=44\&articulo=44-201502\&idioma=en, accessed 15 September, 2015.

Castaño, C., Maiz, I. and Garay, U. (2015b). "Students perceptions of a university MOOC". RIED, 18, 2: 197-224, available from: http://revistas.uned.es/index.php/ried/article/view/13444/13058, accessed 2 September, 2015.

Cheng, J.C.Y. (2014). "An Exploratory Study of Emotional Affordance of a Massive Open Online Course". European Journal of Open, Distance and e-Learning, 17, 1: 43-55, available from: http://www.eurodl.org/?p=archives\&year=2014\&halfyear $=1 \&$ article $=607$, accessed 13 July, 2015.

Chiappe-Laverde, A., Hine, N. y Martínez Silva, J.A. (2015). "Literature and Practice: A Critical Review of MOOCs". Comunicar. Revista Científica de Comunicación y Educación, 44: 9-18, available from: http://www.revistacomunicar.com/index.php?contenido=detalles\&nu mero=44\&articulo=44-2015-01, accessed 2 September, 2015.

Conole, G. (2013). "Los MOOC como tecnologías disruptivas: estrategias para mejorar la experiencia de aprendizaje y la calidad de los MOOC". Campus Virtuales, 2, 16-28, available from: http://www.uajournals.com/campusvirtuales/es/revistaes/numeroactual.html?id=77, accessed 3 September, 2015.

De Waard, I., Abajian, S., Sean Gallagher, M., Hogue, R., Keskin, N., Koutropoulos, A. \& Rodriguez, O. (2011). "Using mLearning and MOOCs to Understand Chaos, Emergence, and Complexity in Education". International Review of Research in Open and Distance Learning, 12, 7, 95-115, available from: http://www.irrodl.org/index.php/irrodl/article/ view/1046, accessed 13 September, 2015.

Delgado Kloos, C., Muñoz-Merino, P.J., Alario-Hoyos, C., Estevez Ayres, I. and Fernández Panadero, C. (2015). Mixing and blending MOOC Technologies with face-to-face pedagogies. In Global Engineering Education Conference (EDUCON), 2015 IEEE, available from: http://ieeexplore.ieee.org/xpls/icp.jsp?arnumber=7096090\&tag=1, accessed 2 July, 2015.

Dillenbourg, P., Fox, A., Kirchner, C., Mitchell, J. y Wirsing, M. (2014). "Massive Open Online Courses: Current state and Perspectives". Dagstuhl Manifestos, 4, 1, 1-27, available from: http://drops.dagstuhl.de/opus/volltexte/2014/4786/pdf/dagman-v004-i001-p001-14112.pdf, accessed 3 July, 2015. 
Ferguson, R. (2012). "Learning analytics: drivers, developments and challenges". International Journal of Technology Enhanced Learning, 4, 5/6, 304-317, available from: http://www. inderscience.com/offer.php?id=51816, accessed 16 September, 2015

Fidalgo, A., Sein-Echaluce, M.L. and García-Peñalvo, F.J. (2015). "Methodological approach and technological framework to break the current limitations of MOOC model". Journal of Computer Science, 21, 5: 712-743, available from: http://www.jucs.org/jucs_21_5/ methodological_approach_and_technological, accessed 15 July, 2015.

Fidalgo, A., Sein-Echaluce, Mª́., Borrás, O. \& García Peñalvo, F.J. (2014). Educación en abierto: integración de un MOOC con una asignatura académica. TESI. Teoría de la Educación. Educación y Cultura en la Sociedad de la Información, 15, 3: 233-255, available from: http://campus.usal.es/ revistas_trabajo/index.php/revistatesi/article/view/12226/12571, accessed 1 September 2015.

Fidalgo, A., Sein-Echaluce, M.L. and García-Peñalvo, F.J. (2013). "MOOC cooperativo. Una integración entre cMOOC y xMOOC", in Fidalgo, A. y Sein-Echaluce M.L. (Eds.). Actas del II Congreso Internacional sobre Aprendizaje, Innovación y Competitividad, CINAIC. Madrid: Fundación General de la Universidad Politécnica de Madrid, 481-486, available from: http://gredos.usal.es/jspui/bitstream/10366/122486/1/DIA_PaperMOOCs.pdf, accessed 15 September, 2015.

Firmin, R., Schiorring, E., Whitmer, J. \& Willett, T. (2014). "Case study: using MOOCs for conventional college coursework". Distance Education, 35 (2): 178-201, available from: http:// www.tandfonline.com/doi/abs/10.1080/01587919.2014.917707, accessed 10 September, 2015.

Gallego, M.J., Gámiz, S. and Gutiérrez, E. (2015). "Tendencias en la evaluación del aprendizaje en cursos en línea masivos y abiertos". Educación XXI, 18, 2: 77-96, available from: http://revistas.uned.es/index.php/educacionXX1/article/viewFile/14596/12996, accessed 15 July, 2015.

García Aretio, L. (2015). “MOOC: ¿tsunami, revolución o moda pasajera?”. RIED, 18, 1: 9-21, available from: http://revistas.uned.es/index.php/ried/article/view/13812/12492, accessed 11 September, 2015

Gasevic, D., Kovanovic, V., Joksimovic, S. and Siemens, G. (2014). "Where is research on massive open online courses headed?. A data analysis of the MOOC Research Initative". The International Review of Research in Open and Distance Learning, 15, 5: 134-175, available from: http://www.irrodl.org/index.php/irrodl/article/view/1954/3099, accessed 13 July, 2015.

Gorard, S. (2004). Combining methods in educational and social research. Maidenhead, Berkshire, UK: Open University Press-McGraw Hill Education.

Gorard, S. and Cook, T. (2007). "Where does good evidence come from?". International Journal of Research \& Method in Education, 30, 3: 307-323, available from: http://www.tandfonline. com/doi/abs/10.1080/17437270701614790?journalCode=cwse20, accessed 11 September 2015.

Guo, P.J. and Reinecke, K. (2014). Demographic Differences in How Students Navigate Through MOOCs. Philip J. Guo and Katharina Reinecke. ACM Conference on Learning at Scale, March 2014, available from: http://www.pgbovine.net/publications/edX-MOOC-demographicsand-navigation_LAS-2014.pdf, accessed 12 September, 2015.

Guo, P.J., Kim, J. and Rubin, R. (2014). How Video Production Affects Student Engagement: An Empirical Study of MOOC Videos. ACM Conference on Learning at Scale, March 2014. Atlanta, Georgia, available from: http://www.pgbovine.net/publications/edX-MOOCvideo-production-and-engagement_LAS-2014.pdf, accessed 4 September, 2015.

Hollands, F.M. and Tirthali, D. (2014). MOOCs: expectations and reality. Full Report. New York: Teachers College, Columbia University, available from: https://oerknowledgecloud. 
org/sites/oerknowledgecloud.org/files/MOOCs_Expectations_and_Reality.pdf, accessed 15 September, 2015.

Israel, M.J. (2015). "Effectiveness of Integrating MOOCs in Traditional Classrooms for Undergraduate Students". The International Review of Research in Open and Distance Learning, 16, 5: 102-118, available from: http://www.irrodl.org/index.php/irrodl/article/view/2222/3437, accessed 13 July, 2015.

Jordan, K. (2014). MOOC Research Literature Browser. Katy Jordan Researching Education and Technology, available from: http://www.katyjordan.com/moocliterature/, accessed 13 July, 2015.

Kennedy, J. (2014). "Characterics of Massive Opne Online Course (MOOCs): A research review, 2009-2012”. Journal of Interactive Online Learning, 13, 1, available from: http://www. ncolr.org/jiol/issues/pdf/13.1.1.pdf, accessed 13 July, 2015.

Knox, J., Bayne, S., MacLeod, H., Ross, J. and Sinclair, C. (2012). MOOC Pedagogy: the challenges of developing for Coursera. Blog Association for Learning Technology, available from: https://altc.alt.ac.uk/blog/2012/08/mooc-pedagogy-the-challenges-of-developing-forcoursera/, accessed 15 September, 2015.

Kop, R., Fournier, H. \& Mak, S.F.J. (2011). A Pedagogy of Abundance or a Pedagogy to Support Human Beings? Participant Support on Massive Open Online Courses. International Review of Research in Open and Distance Learning, Special Issue - Emergent Learning, Connections, Design for Learning, 12, 7, 74-93, available from: http://www.irrodl.org/ index.php/irrodl/article/view/1041/2042, accessed 25 September, 2015.

Lane, L. (2012). Three Kinds of MOOC. Available from: http://lisahistory.net/wordpress/2012/08/ three-kinds-of-moocs/, accessed 10 September, 2015.

Liyanagunawardena, T.R., Adams, A.A. and Williams, S.A. (2013). "MOOC: A Systematic Study of the Published Literature 2008-12". The International Review of Research in Open and Distance Education, 14, 3: 202-227, available from: http://www.irrodl.org/index.php/irrodl/ article/view/1455/2531, accessed 12 July, 2015.

López-Meneses, E., Vázquez-Cano, E. and Román, P. (2015). "Analysis and Implications of the Impact of MOOC Movement in the Scientific Community: JCR and Scopus (2010-13). Comunicar. Revista Científica de Educación y Comunicación, 44: 73-80, available from: http://www.revistacomunicar.com/verpdf.php?numero=44\&articulo=44-2015-08\&idioma=en, accessed 12 July, 2015.

Lowenthal, P.R. and Hodges, Ch.B. (2015). "In Search of Quality: Using Quality Matters to Analyze the Quality of Massive, Open, Online Courses (MOOCs)". The International Review of Research in Open and Distance Learning, 16, 5: 83-100, available from: http:// www.irrodl.org/index.php/irrodl/article/view/2348/3411, accessed 13 July, 2015.

Meyer, E. (2015). "Massive Open Oline Courses (MOOCS): a research brief march 2015". ResearchGate available from: DOI: 10.13140/RG.2.1.4430.6406, accessed 12 September, 2015.

Milligan, C., Littlejohn, A. \& Margaryan, A. (2013). "Patterns of engagement in connectivist MOOCs". Journal of Online Learning and Teaching, 9, 2: 149-159, available from: http:// jolt.merlot.org/vol9no2/milligan_0613.pdf, accessed 15 July, 2015.

Monedero, J. J., Cebrián, D. and Desenne, P. (2015). "Usability and Satisfaction in Multimedia Annotation Tools for MOOCs". Comunicar. Revista Científica de Educación y Comunicación, 44: 55-62, available from: http://www.revistacomunicar.com/verpdf.php?numero=44\&articulo=442015-06\&idioma=en, accessed 8 September, 2015.

Raffaghelli, J., Cucchiara, S. and Persico, D. (2015). "Methodological approaches in MOOC research: Retracting the myth of Proteus". British Journal of Educational Technology, 46, 3: 488-509, available from: http://onlinelibrary.wiley.com/doi/10.1111/bjet.12279/full, accessed 22 July, 2015. 
Reich, J. (2015). "Rebooting MOOC Research. Improve assessment, data sharing and experimental design". Science Magazine, 347, 6217: 34-35, available from: https://www.sciencemag.org/ content/347/6217/34.short?related-urls=yes\&legid=sci;347/6217/34, accessed 22 July, 2015.

Rodriguez, C.O. (2012). MOOC and de AI-Stanford like courses: Two Successful and Distinct Course Formats for Massive Open Online Courses. European Journal of Open, Distance and E-Learning, 2012, II, available from: http://www.eurodl.org/materials/contrib/2012/ Rodriguez.pdf, accessed 25 July, 2015.

Rodriguez, C.O. (2013). The Concept of Openness Behind c and x-MOOC (Massive Open Online Courses). Open Praxis, 5, 1, 67-73, available from: http://openpraxis.org/index.php/ OpenPraxis/article/view/42, accessed 14 September, 2015.

Sandeen, C. (2013). Assessment's place in the new MOOC world. Research \& Practice in Assessment, 8 (1): 5-12

Sangrá, A., González-Sanmamed, M. and Anderson, T. (2015). "Metaanálisis de la investigación sobre MOOC en el período 2013-2014". Educación XXI, 18, 2: 21-59, available from: http:// revistas.uned.es/index.php/educacionXX1/article/view/14594, accessed 2 September, 2015.

Shirky, C. (2013). MOOC and Economic Reality, in The Chronicle of Higher Education $(8,7,2013)$

Siemens, G. (2012). MOOC are Really a Platform, available from: http://www.elearnspace.org/ blog/2012/07/25/moocs-are-really-a-platform/, accessed 18 July 2015.

Siemens, G. (2014). Multiple pathways: Blending xMOOCs and cMOOCs, available from: http:// www.elearnspace.org/blog/2014/05/06/multiple-pathways-blending-xmoocs-cmoocs/, accessed 3 September 2015.

Vargas, J. (2014). "What Can Online Course Designers Learn from Research on Machine-Delivered Instruction?" Academe, 100. 3: 8-12, available from:

http://www.aaup.org/article/what-can-online-course-designers-learn-research-machine-deliveredinstruction\#.VhKPi3tLcaB, accessed 5 September, 2015.

Veletsianos, G. (2013). Learner Experiences with MOOCs and Open Online Learning. Hybrid Pedagogy. Available from: http://hybrid-pedagogy.github.io/LearnerExperiencesInMOOCs/, accessed 10 July 2015.

Vihavainen, A., Luukkainen, M., \& Kurhila, J. (2013). "MOOC as semester-long entrance exam". En Proceedings of the 13th annual ACM SIGITE Conference on Information Technology Education (177-182). ACM, available from: http://dl.acm.org/citation.cfm?doid=2512276.2512305, accessed 3 July, 2015.

Yousef, A.M.F., Chatti, M.A., Schroeder, U., Wosnitza, M. and Jakobs, H. (2015). MOOCs. A review of the state-of-the-art. CSEDU2014 - 6th International Conference on Computer Supported Education, available from: https://oerknowledgecloud.org/sites/oerknowledgecloud. org/files/MOOCs\%20-\%20A\%20Review\%20of\%20the\%20State-of-the-Art.pdf, accessed 2 September 2015.

Yuan, L. \& Powell, S. (2013). "MOOC and Open Education: Implications for Higher Education". CETIS: Centre for Educational Technology, Interoperability and Standards, White Paper, WP03, available from: http://publications.cetis.org.uk/2013/667, accessed 2 July, 2015.

Yuan, L., and Powell, S. (2013). MOOCs and open education: Implications for higher education. JISC Cetis White Paper, available from: http://publications.cetis.org.uk/2013/667, accessed 4 September 2015.

Zhang, D.J. et al. (2015). "Does Social Interaction improve service Quality?. Field Evidence from Massive Open Online Education". Kellogg School of Management, Northwestern University, Evanston, IL, available from: http://www.kellogg.northwestern.edu/faculty/vanmieghem/ htm/pubs/mooc_zhang-allon-vanmieghem_9_21_2015.pdf, accessed 23 September 2015. 